LEwin, J. C. (1955). J. gen. Microbiol. 13, 162-169.

\title{
The Capsule of the Diatom Navicula pelliculosa
}

\author{
BY JOYCE C. LEWIN \\ Osborn Botanical Laboratory, Yale University, Nerv Haven, Connecticut, U.S.A. \\ and Maritime Regional Laboratory*, National Research Council, Halifax, Nova \\ Scotia, Canada
}

SUMMARY: The cells of Navicula pelliculosa become invested in a gelatinous capsule when they cease to divide. This may occur when the culture medium becomes depleted of some necessary element, such as silicon, phosphorus, or nitrogen. A method for the extraction of the capsular fraction has been devised, which is based on its solubility in $20 \%(\mathrm{w} / \mathrm{v}) \mathrm{NaOH}$. It is a polyuronide, apparently consisting solely of glucuronic acid residues.

According to Mangin (1908) Bailey in 1851 was the first to mention an organic membrane regularly associated with the siliceous valves of diatoms. Mangin showed, by the use of stains, that there was no cellulose present in the cell walls of diatoms, and stated that diatoms were distinct from all other organisms in their possession of a membrane composed of pectic compounds alone. He showed that, like pectin, the material stained with ruthenium red, methylene blue, safranin, neutral red, naphthyl blue, and alum haematoxylin. The 'pectic' membrane and external envelope remained after his diatoms were digested with hydrofluoric acid, which dissolved the siliceous skeletons. In addition to this membrane, gelatinous pads, stalks, tubes, or envelopes are characteristic of many diatom species. These external secretions have been considered to be of the same chemical nature as the pectic membrane, in that they give similar staining reactions (Liebisch, 1929). So far as the writer is aware, no chemical analysis of this pectic compound has been made hitherto.

Kützing's original description of Navicula pelliculosa (Synedra minutissima $\beta$ pelliculosa) in 1849 made reference to a gelatinous capsule-'Individua in gelatina membranacea nidulantia'-which has given the organism its present specific name (Germain, 1935). Locker (1950) grew this species in culture and observed that the capsule stained with ruthenium red or safranin. She also referred to slime on the surface of ponds, which can be attributed to this organism when it is present in abundance.

Navicula pelliculosa (Bréb. ex Kütz.) Hilse has been independently isolated in pure culture. There is no evident capsule around actively dividing cells, but capsular material appears to accumulate after the cessation of cell multiplication. It can be made more visible by mounting the cells in nigrosin (see Pl. 1, fig. 1) or by direct staining with toluidine blue or methylene blue; in the latter cases some shrinking of the capsule occurs. The present paper deals with the extraction and partial characterization of this material, and with nutritional factors affecting capsule formation by the cells.

* Present address, as guest research worker. 


\section{Isolation of the organism}

The strain of Navicula pelliculosa used in these studies was obtained by streaking a sample of water from a Connecticut pond on agar containing minerals but no organic supplement. Colonies were visible on the surface after a 4-day illumination period. Organisms from one of these colonies were suspended in sterile water and restreaked on a second plate, and by repetition of this procedure the diatom was isolated in pure culture. Tests for the presence of bacteria were carried out by inoculation into glucose Tryptone media and by microscopic examination. The diatom culture has been maintained on agar slopes in test tubes, with transfer to fresh media every 2 months.

\section{Growth medium and culture methods}

The mineral medium used contained the following concentrations of salts $(\%, \mathrm{w} / \mathrm{v}): \mathrm{K}_{2} \mathrm{HPO}_{4}, 0.02 ; \mathrm{MgSO}_{4} .7 \mathrm{H}_{2} \mathrm{O}, 0.02 ; \mathrm{Ca}\left(\mathrm{NO}_{3}\right)_{2} .4 \mathrm{H}_{2} \mathrm{O}, 0.1$ in distilled water. Traces of $\mathrm{B}, \mathrm{Mn}, \mathrm{Zn}, \mathrm{Cu}, \mathrm{Mo}$ and $\mathrm{Fe}$ were added. Silicon was added as potassium silicate ('Solution Silicate of Potash', Fisher, New York), giving a soluble silicon concentration of 1-3 mg. Si/l. (unless otherwise specified). At this concentration, silicon is limiting for growth but capsule accumulation is enhanced.

Mass cultures of organisms for chemical analysis were grown under aseptic conditions in $12 \mathrm{l}$. bottles containing $10 \mathrm{l}$. of inorganic culture medium. The organisms were illuminated by 'White' fluorescent tubes, and aerated with compressed air sterilized by passage through a cotton filter. Cultures for the study of the nutritional factors affecting capsule formation were grown in $125 \mathrm{ml}$. Pyrex Erlenmeyer flasks, containing $25 \mathrm{ml}$. liquid/flask. These flasks were shaken constantly at 60 oscillations/min. on a glass-bottomed extension attached to an Eberbach shaking machine. Illumination of $\mathbf{3 0 0} \mathrm{ft}$. candles was provided by four 'White' fluorescent lamps below the extension, and the position of the flasks was changed daily to ensure a uniform average illumination. All cultures were grown at $23^{\circ}$.

\section{Preparation of organisms for extraction}

The organisms from $10 \mathrm{l}$. of culture medium were allowed to settle, and the supernatant solution poured off. Sufficient $\mathrm{HCl}$ was added to the remaining suspension to dissolve precipitated calcium phosphates. The organisms were concentrated by centrifugation and the total wet weight of the sludge determined. From the wet weight and dry weight of a small sample, the dry weight of the whole mass of organisms was calculated. Yields of from 2 to $3 \mathrm{~g}$. (dry weight) were obtained.

\section{Extraction of the capsular material}

Preliminary investigations revealed that the capsule material of Navicula pelliculosa was insoluble in cold or hot water. Attempts were made to dissolve the diatom capsule by following the standard methods employed for the 
extraction of angiosperm pectins (Loomis \& Shull, 1937; Bonner, 1950). At each stage a sample of the insoluble cell residue was stained and examined microscopically; the extract was neutralized, when necessary, and treated with excess ethanol to precipitate any extracted capsular material.

The diatom capsule was insoluble in hot $0.5 \%(\mathrm{w} / \mathrm{v})$ oxalic acid (a solvent for protopectin), insoluble in $0.5 \%(\mathrm{w} / \mathrm{v})$ ammonium oxalate (a solvent for pectic acid), insoluble in Schweitzer's reagent, cupric-ammonium hydrate (a solvent for cellulose), slightly soluble in cold $5 \%(\mathrm{w} / \mathrm{v}) \mathrm{NaOH}$, and rendered soluble by cold $20 \%$ (w/v) $\mathrm{NaOH}$. After dilution, neutralization, and filtration of the $20 \% \mathrm{NaOH}$ extract, and after addition of $\mathrm{CaCl}_{2}$ ( 1 vol. $\mathrm{M}-\mathrm{CaCl}_{2}$ to 6 vol. extract) and ethanol (1 vol. of $95 \%$ ethanol in water to 1 vol. extract), a gummy white flocculum precipitated. This precipitate was coagulated by heating, collected, washed with water and ethanol, dried and weighed. The dried material swelled rapidly in water without dissolving and was found to retain the staining properties exhibited by the capsule of intact organisms.

In subsequent analyses the organisms were first extracted with $80 \%$ (v/v) ethanol in water to remove sugars, fatty constituents, some pigments, etc., then with $5 \%(\mathrm{w} / \mathrm{v}) \mathrm{NaOH}$ which saponified and removed most of the chlorophyll persisting after the ethanol extraction; finally the capsule was dissolved in $20 \% \mathrm{NaOH}$. The yields obtained in several experiments showed that the capsule material accumulated as the culture aged, confirming the microscopic observations. The extracted capsular material represented $17 \%$ of the dry weight of organisms from a 12-day culture; $37 \%$ from a 20-day culture; 42 and $50 \%$ from 27 -day cultures.

\section{Chemical characterization of the capsular material}

Micro-Kjeldahl determinations for organic nitrogen, based on the method of Ma \& Zuazaga (1942), were carried out on samples of extracted diatom capsule. Only $\mathbf{0 . 2} \%$ nitrogen was found, corresponding to not more than $\mathbf{1 . 2} \%$ protein and indicating that little or no mucoprotein was present.

Samples $\left(10 \mathrm{mg}\right.$.) of dried capsular material were hydrolysed at $100^{\circ}$ for $5 \mathrm{hr}$. in sealed glass ampoules with $1 \mathrm{ml} .0 \cdot 5 \mathrm{~N}-, 1 \cdot 0 \mathrm{~N}-, 2 \cdot 0 \mathrm{~N}-$, or $4 \cdot 0 \mathrm{~N}-\mathrm{H}_{2} \mathrm{SO}_{4}$, or $87 \%$ formic acid. The hydrolysates were diluted to $10 \mathrm{ml}$. and neutralized with $\mathrm{BaCO}_{3}$ to about $\mathrm{pH} 5.0$ (Congo red). The $\mathrm{BaSO}_{4}$ and excess $\mathrm{BaCO}_{3}$ were removed by centrifugation and the supernatant fluid evaporated to $1 \mathrm{ml}$. on a boiling water bath. Samples of these solutions were then chromatographed by descending migration. Drops of these solutions were applied with a wire loop $8 \mathrm{~cm}$. from the edge of a sheet of Whatman no. 1 filter paper $\left(20 \frac{1}{4} \times 18 \frac{1}{2} \mathrm{in}\right.$.). Standards of $4 \mathrm{mg}$. samples of sugars and uronic acids were run as controls. Migration was carried out in a 'Chromatocab', model A (Research Equipment Corporation, Oakland, California, U.S.A.) and the time of the run depended on the solvent.

The solvents used were: (1) $n$-butanol/ethanol/water, 4:1:5 (Flood, Hirst \& Jones, 1948); (2) $n$-butanol/glacial acetic acid/water, 4:1:5 (Partridge, 1948); (3) acetone/water/formic acid, 9:1:1 (Evans \& Mehl, 1951, modified by Dr C. 
Partridge, unpublished). The developing reagents, used as spray, were: (1) $0.2 \%$ ethanolic solution of naphthoresorcinol, acidified with 0.1 vol. of orthophosphoric acid (Bryson \& Mitchell, 1951); (2) $3 \% p$-anisidine hydrochloride in $n$-butanol (Hough, Jones \& Wadman, 1950).

In preliminary experiments with butanol/ethanol/water as solvent, the hydrolysate moved only a short distance relative to the control sugars, indicating the presence of a uronic acid. No pentoses or hexoses were detected. Samples of commercial galacturonic and glucuronic acids were run for comparison. Glucuronic acid lactone was partially converted to the free acid by hydrolysis with $0.5 \mathrm{~N}-\mathrm{H}_{2} \mathrm{SO}_{4}$ as described above. The capsule hydrolysate migrated at the same rate as did the known uronic acids, both in solvents (1) and (2). The $R_{F}$ values obtained with these solvents are shown in Table 1. Capsular material hydrolysed with $2 \mathrm{~N}-\mathrm{H}_{2} \mathrm{SO}_{4}$ or $87 \%$ formic acid also gave a spot which corresponded with the glucuronic lactone spot. The spot given by the hydrolysate of capsule material gave the same colour with $p$-anisidine as did the uronic acid controls (cherry red).

Table 1. Relative migration distances $\left(\boldsymbol{R}_{F}\right.$ values $)$ of hydrolysis products of capsular material from Navicula pelliculosa and known markers in various solvent mixtures

\begin{tabular}{|c|c|c|c|c|c|}
\hline Compound & $\begin{array}{l}\text { Solvent 1,* } \\
\quad 21 \mathrm{hr} \text {. }\end{array}$ & $\begin{array}{l}\text { Solvent 1, } \\
21 \mathrm{hr} .\end{array}$ & $\begin{array}{c}\text { Solvent } 2 \\
18 \mathrm{hr} .\end{array}$ & $\begin{array}{l}\text { Solvent 3, } \\
11 \mathrm{hr} ., \\
\text { off end } \dagger\end{array}$ & $\begin{array}{l}\text { Solvent } 3 \\
5 \mathrm{hr} .\end{array}$ \\
\hline Xylose & 0.32 & $0 \cdot 27$ & $0 \cdot 33$ & $0 \cdot 67$ & $0 \cdot 67$ \\
\hline Galacturonic acid & $\begin{array}{c}0.22, \\
\text { forward trail }\end{array}$ & $0 \cdot 18$ & $0 \cdot 22$ & $0 \cdot 58$ & 0.63 \\
\hline Glucuronic acid & 0.04 & - & $0 \cdot 20$ & 0.63 & 0.62 \\
\hline Glucuronic lactone & 0.411 & 0.35 & 0.42 & - & 0.76 \\
\hline \multicolumn{6}{|c|}{ Diatom capsule hydrolysed in: } \\
\hline $\mathrm{N}-\mathrm{H}_{2} \mathrm{SO}_{4}$ & - & - & - & $0 \cdot 62$ & - \\
\hline $2 \mathrm{~N}-\mathrm{H}_{2} \mathrm{SO}_{4}$ & $0 \cdot 08,0 \cdot 40$ & - & - & $0 \cdot 63$ & $0 \cdot 64,0 \cdot 73$ \\
\hline $4 \mathrm{~N}-\mathrm{H}_{2} \mathrm{SO}_{4}$ & - & - & $0 \cdot 20$ & - & - \\
\hline $87 \%$ formic acid & - & $\begin{array}{c}0.35, \\
\text { slight spot } \\
\text { at } 0 \cdot 16\end{array}$ & - & - & - \\
\hline
\end{tabular}

To distinguish between glucuronic and galacturonic acids, solvent (3) was used. The results shown in Table 1 indicate that the capsule material does not consist of galacturonic acid, but might be glucuronic or mannuronic acid. Dr J. K. N. Jones (Queen's University, Kingston, Ontario, Canada) subsequently confirmed the presence of glucuronic acid residues only (personal communication).

\section{Nutritional factors which affect capsule formation}

Preliminary experiments indicated that capsule formation took place only at the end of the exponential phase of growth. To confirm this diatoms were grown in silicon-deficient, nitrogen-deficient, and phosphorus-deficient media 
(Table 2); at intervals the density of growth was determined and the cells examined microscopically for capsule formation. From the results obtained (Fig. 1), it can be seen that in each case capsule formation occurred only when cell division was inhibited by depletion of the limiting element. Silicon determinations at the end of 15 days revealed $21.6 \mathrm{mg}$. Si/l. in the phosphorusdeficient culture, $7 \cdot 3 \mathrm{mg}$. Si/l. in the nitrogen-deficient culture, and $\mathbf{0 . 2} \mathrm{mg}$. $\mathrm{Si} / \mathrm{l}$. in the control and silicon-deficient cultures.

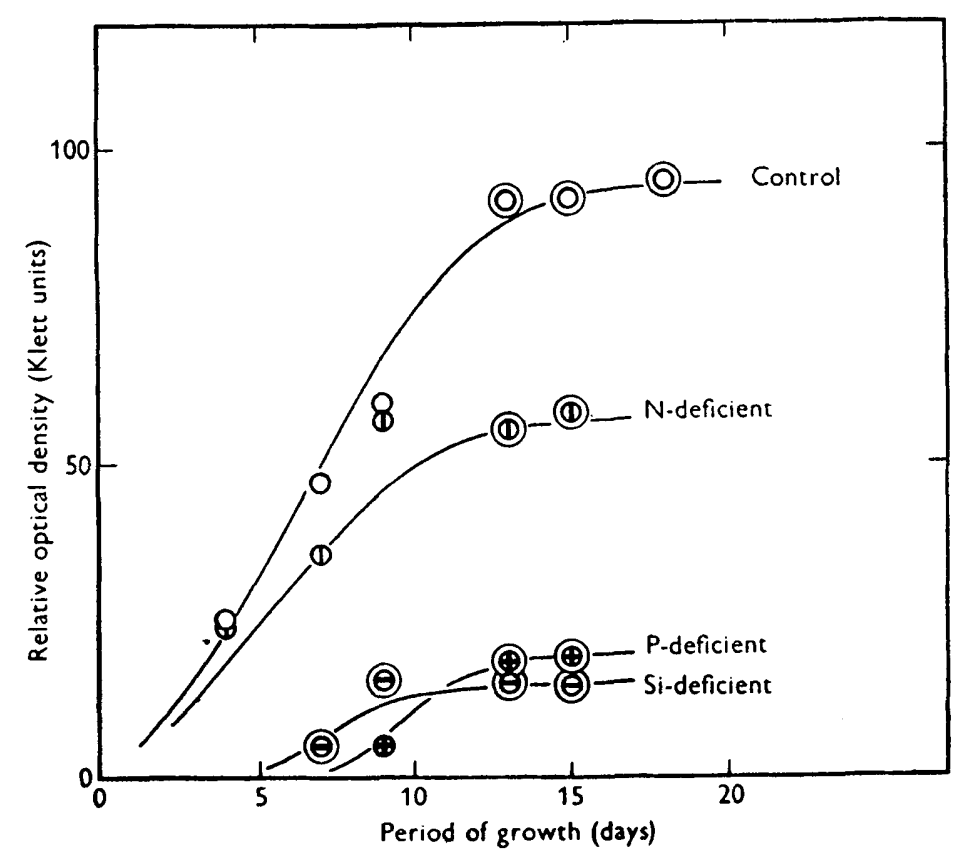

Fig. 1. Growth and capsule formation of Navicula pelliculosa in various nutrient media. Double circles indicate when capsules were visible microscopically. (The control flasks became Si-deficient after 10 days.)

When capsulated cells were transferred to a complete nutrient medium, cell division began again, and the cells so formed, lacking capsules, ultimately burst out and were liberated from the parental capsule.

Table 2. Chemical composition of media employed in nutrition experiments with Navicula pelliculosa

Compound

Potassium silicate

$\mathrm{MgSO}_{4} .7 \mathrm{H}_{2} \mathrm{O}$

$\mathrm{Ca}\left(\mathrm{NO}_{3}\right)_{2} \cdot 4 \mathrm{H}_{2} \mathrm{O}$

$\mathrm{K}_{2} \mathrm{HPO}_{4}$

$\mathrm{KCl}$

$\mathrm{CaCl}_{2} \cdot 2 \mathrm{H}_{2} \mathrm{O}$

Trace elements

\begin{tabular}{|c|c|c|c|}
\hline Control & Si-deficient & P-deficient & $\mathrm{N}$-deficient \\
\hline $30 \mathrm{mg} . \mathrm{Si} / \mathrm{l}$. & $3 \mathrm{mg} . \mathrm{Si} / \mathrm{l}$ & $30 \mathrm{mg} . \mathrm{Si} / \mathrm{l}$. & $30 \mathrm{mg} . \mathrm{Si} / \mathrm{l}$ \\
\hline $0 \cdot 2 \mathrm{~g} . / 1$ & $0.2 \mathrm{~g} . / 1$ & $0.2 \mathrm{~g} . / \mathrm{l}$ & $0.2 \mathrm{~g} . / \mathrm{l}$ \\
\hline $1.0 \mathrm{~g} . / 1$. & $1.0 \mathrm{~g} . / \mathrm{l}$. & $1.0 \mathrm{~g} . / \mathrm{l}$ & $0.1 \mathrm{~g} . / \mathrm{l}$. \\
\hline $0 \cdot 2 \mathrm{~g} . / 1$ & $0.2 \mathrm{~g} . / 1$. & 0.02 g. $/ \mathrm{l}$ & $0.2 \mathrm{~g} . / 1$. \\
\hline - & - & $0.17 \mathrm{~g} . / \mathrm{l}$ & - \\
\hline - & - & - & 0.62 g./l. \\
\hline $1 \mathrm{ml} . / \mathrm{l}$. & $1 \mathrm{ml} . / \mathrm{l}$. & $1 \mathrm{ml} . / 1$. & $1 \mathrm{ml} . / \mathrm{l}$. \\
\hline
\end{tabular}




\section{DISCUSSION}

The capsular polyuronide of Navicula pelliculosa can no longer be regarded as pectin, since it is a polymer of glucuronic and not of galacturonic acid. It remains to be determined in what way the uronic acid residues are linked in the natural polymer, and whether the latter is combined in some way with protein or with the silica walls, which might account for its peculiar insolubility in dilute alkalies.

It has been suggested that in various diatoms gelatinous secretions may play a role:

(a) In locomotion (see Fritsch, 1935). However, it is only the non-capsulated cells of Navicula pelliculosa which have been observed to exhibit motility.

(b) As a flotation device for planktonic forms (Naumann, 1925).

(c) As an attachment mechanism. In many diatom species the cells are enclosed in tubes, or adhere to one another or to the substrate by stalks or pads.

(d) As a protection against aquatic herbivores. Undigested and living cells of Navicula spp. were found in the excreta of water animals (Michaelis, 1915).

(e) As a mechanism for dissolving siliceous minerals such as kaolin (Vinogradov \& Boichenko, 1942).

$(f)$ As a means of protecting the cell against desiccation, due to the ability of the material to absorb many times its own weight of water. However, experiments by the present author indicated no such protection.

(g) As an extracellular food reserve. But encapsulated cells of Navicula pelliculosa, stored in the dark for a period of several weeks on a mineral medium, showed no decrease in the size of the capsules. The organisms apparently do not produce extracellular enzymes capable of hydrolysing their polyuronide capsules. Moreover, although these diatoms can grow and can form capsules in the dark on glucose, they are unable to grow when supplied with a hydrolysate of the extracted capsular material, or with glucuronic or galacturonic acid, as sole carbon source (Lewin, 1953).

(h) As an accumulation of a waste product. In certain bacteria (e.g. Leuconostoc spp.) polysaccharides are formed from carbohydrate units not utilized by the cell, and are secreted and accumulated in the form of a capsule.

The accumulation of capsular material by Navicula pelliculosa occurs when some nutrient in the culture medium becomes limiting, and growth is thereby inhibited. Organisms in such deficient media continue to photosynthesize, and part of the synthesized material appears ultimately as polyuronide, which gradually accumulates around the organisms. The presence of a capsule thus reflects a state of poor nutrient conditions; its function, if any, has not been determined. It is possible that the widespread occurrence of sheaths, capsules, mucilage tubes, etc., among various diatom species is likewise an indication of the limiting concentration of some essential nutrient in natural waters. These results are similar to those observed in Aerobacter aerogenes (Duguid \& Wilkinson, 1953). In cultures of this bacterium, production of 
polysaccharide (intracellular, capsular, and slime fractions) increased when growth was limited by deficiency of an essential nutrient such as nitrogen or phosphorus, providing the carbon source was not depleted.

Diatoms are among the most abundant photosynthetic organisms in fresh water and the oceans, and the total annual crop of these algae may compare favourably with that of land plants (Allen, 1934; Steemann Nielsen, 1952). The polysaccharides associated with their cell walls may therefore be among the most abundantly formed organic materials in the world, and this may be of considerable significance in plankton ecology. It would therefore be of some importance to determine whether Navicula pelliculosa is exceptional in its production of a polyglucuronide capsule, or whether this material is of general occurrence in the membranes of the Bacillariophyta.

Some of the material presented in this paper was submitted in 1952 as part of a Ph.D. thesis at Yale University. The author wishes to express thanks to Dr Paul R. Burkholder and to Dr Ralph A. Lewin for many helpful suggestions, to Dr Ruth Patrick, Academy of Natural Sciences of Philadelphia, for the identification of the diatom species, to Dr Chester Partridge, Yale University, for aid and advice on techniques in paper chromatography, and to Dr E. G. Young for a critical reading of the manuscript. Dr J. K. N. Jones, Queen's University, Kingston, Ontario, Canada, examined a sample of the capsule material, and confirmed the presence of glucuronic acid in hydrolysates; his expert cooperation in this matter is gratefully acknowledged.

This paper is issued as N.R.C. no. 3652 .

\section{REFERENCES}

Allen, W. E. (1934). The primary food supply of the sea. Quart. Rev. Biol. 9, 161. Bonner, J. (1950). Plant Biochemistry. New York: Academic Press Inc.

Bryson, J. L. \& Mitchell, T. J. (1951). Improved spraying reagents for the detection of sugars on paper chromatograms. Nature, Lond., 167, 864.

Duguid, J. P. \& Wilkinson, J. F. (1953). The influence of cultural conditions on polysaccharide production by Aerobacter aerogenes. J. gen. Microbiol. 9, 174.

Evans, E. E. \& MEHL, J. W. (1951). A qualitative analysis of capsular polysaccharides from Cryptococcus neoformans by filter paper chromatography. Science, 114, 10.

Flood, A. E., Hirst, E. L. \& Jones, J. K. N. (1948). Quantitative analysis of mixtures of sugars by the method of partition chromatography. Part I. Standardization of procedure. J. chem. Soc. p. 1679.

Fritsch, F. E. (1935). The Structure and Reproduction of the Algae, Vol. I. Cambridge University Press.

Germain, H. (1935). Les lieux de développement et de multiplication des diatomées d'eau douce. Thèses présentées à la Faculté des Sciences de Bordeaux. Angers: L'Imprimerie de l'Anjou.

Hough, L., Jones, J. K. N. \& Wadman, W. H. (1950). Quantitative analysis of mixtures of sugars by the method of partition chromatography. Part V. Improved methods for the separation and the detection of the sugars and their methylated derivatives on the paper chromatogram. J. chem. Soc. p. 1702.

LEwin, J. C. (1953). Heterotrophy in diatoms. J. gen. Microbiol. 9, 305.

Liebisch, W. (1929). Experimentelle und kritische Untersuchungen über die Pektinmembran der Diatomeen unter besonderer Berücksichtigung der Auxosporenbildung und der Kratikularzustände. Z. Bot. 22, 1. 
Journal of General Microbiology, Vol. 13, No. 1

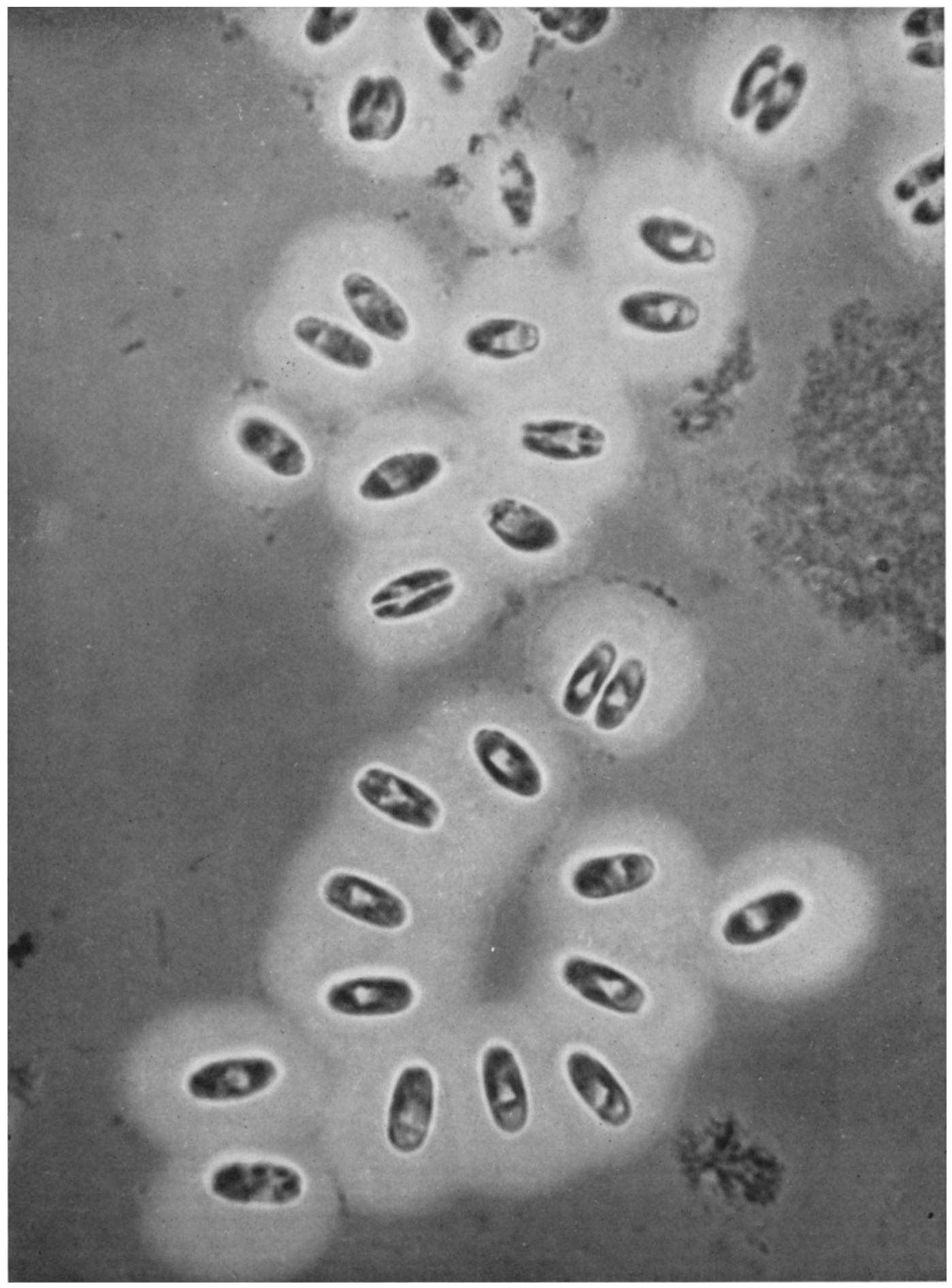

J. C. Ifewin - Capsule of Natictla pelatcllosa. Plate 1 
Locker, F. (1950). Beiträge zur Kenntnis des Formwechsels der Diatomeen an Hand von Kulturversuchen. Öst. bot. Z. 97, 322.

Loomis, W. E. \& Shull, C. A. (1937). Methods in Plant Physiology. New York: MeGraw-Hill Book Co. Inc.

MA, T. S. \& ZUAZAGA, G. (1942). Micro-Kjeldahl determination of nitrogen, a new indicator and an improved rapid method. Industr. Engng Chem. 14, 280.

Mangin, M. L. (1908). Observations sur les Diatomées. Ann. sci. nat. Botan. et biol. végétale. 8,177 .

Michaelis, H. (1915). Biologische Studien über Schutzmittel gegen Tierfrass bei Süsswasseralgen. Inaug.-Dissert. Schoenberg (Mecklenburg).

NaUmann, E. (1925). Gallertbildungen des pflanzlichen Limnoplanktons. Lunds Univ. Arsskr. 21, 1.

Partridge, S. M. (1948). Filter-paper partition chromatography of sugars. 1. General description and application to the qualitative analysis of sugars in apple juice, egg white, and foetal blood of sheep. Biochem. J. 42, 238.

Steemann Nrelsen, E. (1952). Production of organic matter in the sea. Nature, Lond. 169, 956.

Vinogradov, A. P. \& Boichenko, E. A. (1942). Decomposition of kaolin by diatoms. C.R. Acad. Sci. U.R.S.S. 37, 135.

\section{EXPLANATION OF PLATE}

Fig. 1. Photomicrograph showing capsules surrounding cells of Navicula pelliculosa. Nigrosin preparation. $\times 1750$.

(Received 4 February 1955) 